ROCZNIKI PEDAGOGICZNE

Tom 12(48), numer $3-2020$

DOI: https://doi.org/10.18290/rped20123-2

ANTONI GRZESIUK

\title{
DALEKOWZROCZNE CELE EDUKACJI KOMUNIKACYJNEJ W TWORZENIU BEZPIECZEŃSTWA RUCHU DROGOWEGO A PROCES EGZAMINOWANIA KIERUJĄCYCH POJAZDEM
}

\section{WPROWADZENIE}

Transport jest jednym z najważniejszych wyzwań przyszłości, jest „krwioobiegiem" gospodarki. Rozwój komunikacji i transportu stymuluje postęp techniczny i kulturowy, równocześnie niesie ze sobą zagrożenia. Poziom bezpieczeństwa w ruchu drogowym klasyfikuje Polskę na jednym z ostatnich miejsc w Europie. Nadzieją na poprawę bezpieczeństwa w ruchu drogowym jest edukacja. Jest też ona szansą na tworzenie skutecznych projektów poprawy bezpieczeństwa w ruchu drogowym. Edukacja przez całe życie pozwala na budowanie programów tworzących nową jakość bezpieczeństwa. Rozwój wyobraźni, antycypacyjne myślenie i zapobieganie zagrożeniom zależą od wykształcenia społeczeństwa. Wychowanie komunikacyjne dzieci i młodzieży jest drogą tworzącą kulturę bezpieczeństwa. Należy na nowo określić i sprecyzować dalekie oraz bliskie cele kształcenia kierowców, ze szczególnym uwzględnieniem celów wychowawczych i poznawczych.

Skonkretyzowane, operacyjne cele kształcenia pozwolą na dobór skutecznych, wysokojakościowych treści kształcenia w postaci istotnych wyselekcjonowanych strukturalnych informacji oraz ćwiczeń dobranych do psychicznych procesów kształcących. Aby system kształcenia kandydatów na kierowców był skuteczny, należy kształcić wykładowców, instruktorów i egzaminatorów na wyższym poziomie. Dla bezpieczeństwa ruchu drogowego powinno się tworzyć elity dydaktyczne. W systemie egzaminowania kandydatów na kierowców istnieje potrzeba opracowania profesjonalnych narzędzi po-

Dr Antoni GrZesıUK - Instytut Psychologii, Katolicki Uniwersytet Lubelski Jana Pawła II, adres do korespondencji: Al. Racławickie 14, 20-950 Lublin; e-mail: antoni.grzesiuk@wp.pl. 
miaru dydaktycznego w postaci psychologicznych i dydaktycznych testów, które, jako narzędzia formalnego pomiaru, należy poddać standaryzacji. Trzeba zerwać z pozorami kształcenia i pozorami egzaminowania kierujących w zakresie wiedzy i jej rozumienia. Aby wpłynąć na poprawę bezpieczeństwa ruchu drogowego, należy rozstać się ze sztywnym habitem krępującym proces szkolenia i egzaminowania kierowców, sztywnością kryterialną i proceduralną, konfliktowaniem zdających, instruktorów i egzaminatorów. Trzeba budować bezpieczeństwo w ruchu drogowym, uczyć ludzi, jak chronić najwyższe wartości, jakimi są życie i zdrowie.

Stąd też transport, będąc jednym z najważniejszych wyzwań przyszłości, jest jednocześnie - powtórzmy - „krwioobiegiem” gospodarki, gdyż usprawnia przepływ towarów i usług oraz osób. Liczba pojazdów samochodowych rośnie trzy razy szybciej niż przyrost ludności, natomiast rozwój sieci drogowej jest nieproporcjonalny do wzrostu użytkowników samochodów. Indywidualizacja przemieszczania się powoduje zatłoczenie dróg. Koncentracja przemysłu i struktura dystrybucji towarów wpływają na wzrost kilometrażu przewozu osób i rzeczy. Rozkwit motoryzacji skłania do rozproszenia biegunów miejskiego i pozamiejskiego życia, miejsc zamieszkania, nauki i pracy. Wzrost liczby pojazdów oraz kilometrażu przewozu rzeczy i osób przyczyniają się do wzrostu zagrożeń w ruchu drogowym.

\section{ZAGROŻENIA W RUCHU DROGOWYM}

Według danych Banku Światowego (2013) ${ }^{1}$ oraz danych Komendy Głównej Policji ${ }^{2} \mathrm{z}$ ostatniego dziesięciolecia każdego roku ginie na świecie kilkaset tysięcy ludzi, a rannych jest wielokrotnie więcej. Dwie trzecie ofiar wypadków drogowych to piesi, z tego jedną trzecią stanowią dzieci.

Corocznie na świecie w wyniku wypadków drogowych ginie prawie 1,3 miliona osób, a od 20 do 50 milionów osób cierpi z powodu doznanych obrażeń. Ponad 90\% śmiertelnych wypadków drogowych ma miejsce w krajach o średnich i niskich dochodach. W marcu 2010 r. Organizacja Narodów Zjednoczonych (ONZ) ogłosiła „Dekadę działań na rzecz bezpieczeństwa ruchu drogowego na lata 2011-2020", której celem jest powstrzymanie wzrostu, a następnie zmniejszenie liczby zabitych w wypadkach drogowych. Globalny

\footnotetext{
${ }^{1}$ Report nr 78319 Banku Światowego, Raport końcowy Przegląd potencjału w zakresie zarządzania bezpieczeństwem drogowym w Polsce (tłumaczenie z języka angielskiego), czerwiec 2013.

${ }^{2}$ www.policja.pl (dane Komendy Głównej Policji).
} 
Plan ONZ w ramach „Dekady działań na rzecz bezpieczeństwa drogowego na lata 2011-2020” bazuje na metodologii „Bezpieczny System” (Safe System), której fundamentem jest zasada wspólnej odpowiedzialności za budowanie bezpieczeństwa drogowego. Zachęca on kraje do wdrażania działań w oparciu na Pięciu Filarach:

- zarządzanie bezpieczeństwem ruchu drogowego;

- bezpieczniejsza infrastruktura drogowa i mobilność;

- bezpieczniejsze pojazdy;

- bezpieczni użytkownicy ruchu drogowego;

- ratownictwo i opieka powypadkowa.

W krajach Unii Europejskiej w latach 2001-2011 liczba ofiar śmiertelnych w wypadkach drogowych spadła średnio o $45 \%$, w Polsce jedynie o $24 \%$. W 2001 r. śmiertelność w wypadkach drogowych w Polsce była na tym samym poziomie co w Belgii i Estonii, lecz niższa niż wskaźniki dla Grecji, Łotwy, Litwy, Luksemburga i Portugalii. Do 2011 r. sytuacja we wszystkich wymienionych krajach poprawiła się, natomiast Polska stała się krajem o najwyższym wskaźniku śmiertelności, wynoszącym 110 zabitych na milion mieszkańców. Średni wskaźnik śmiertelności w Unii Europejskiej wynosi 60.

$\mathrm{Z}$ tych danych liczbowych jasno wynika, że w państwach członkowskich UE, które miały porównywalne wskaźniki śmiertelności, odnotowano postęp, którego nie udało się osiągnąć w Polsce. To względne pogorszenie sytuacji Polski na tle Unii Europejskiej wskazuje na pilną potrzebę podjęcia działań zaradczych. Polska jest sygnatariuszem Deklaracji ONZ w sprawie bezpieczeństwa ruchu drogowego, a jako państwo członkowskie UE jest zobowiązana do realizacji konkretnych polityk unijnych, w tym polityki w zakresie poprawy bezpieczeństwa drogowego, zawartej w dokumencie zatytułowanym: „W stronę europejskiego obszaru bezpieczeństwa ruchu drogowego: kierunki polityki bezpieczeństwa ruchu drogowego na lata 2011-2022". Dokument ten zakłada podtrzymanie celu, którym jest zmniejszenie o połowę liczby śmiertelnych ofiar wypadków drogowych w Unii Europejskiej do roku 2020, w stosunku do roku bazowego 2010.

Raport ten akcentuje „dodanie” dla Polski nowego celu „Bezpieczna prędkość", uznając, że jednym z głównych problemów w Polsce są wypadki spowodowane nadmierną prędkością. Cel został ogłoszony w dniu 9 stycznia 2013 r. przez Ministerstwo Transportu i Ministerstwo Spraw Wewnętrznych w czasie inauguracji konsultacji Narodowego Programu Bezpieczeństwa Ruchu Drogowego. 


\section{BUDOWANIE BEZPIECZEŃSTWA RUCHU DROGOWEGO}

Transport jest branżą o dużej inercji. Procedury decyzyjne i wdrożeniowe są długotrwałe, a na skutki reform trzeba długo czekać. Techniczna infrastruktura, budowa dróg, hipersamochodów, systemów bezpieczeństwa wymagają czasu i ogromnych nakładów środków finansowych. Trzeba zgodzić sie z wielkim wizjonerem, jakim jest Federico Mayor (2011), że do najważniejszych problemów zintegrowanej strategii poprawy bezpieczeństwa w ruchu drogowym należy zaliczyć:

- doskonalenie prac diagnostycznych i prognostycznych transportu i ruchu drogowego,

- prowadzenie badań nad budową sieci drogowej hiperpojazdów i systemów bezpieczeństwa drogowego,

- opisywanie przyczyn wypadków drogowych i zarządzanie bezpieczeństwem ruchu drogowego,

- tworzenie systemu edukacji komunikacyjnej oraz wzorów bezpieczeństwa w ruchu drogowym.

Nie możemy dokładnie przewidzieć, jak będzie w przyszłości skonstruowany system komunikacji, transport oraz ruch drogowy. Z całą pewnością będzie taki, na jaki nas stać i jaki potrafimy zbudować. Jak pisał Paul Valery (2001) ,przyszłość jest budową”.

Poziom bezpieczeństwa na naszych drogach będzie taki, jaki będzie poziom elit tworzących scenariusze przyszłości, projekty komunikacyjne oraz prawo o ruchu drogowym. Bezpieczeństwo w ruchu drogowym będzie zależne od analizy teraźniejszego systemu komunikacji oraz od antycypacji przyszłości, przewidywania zagrożeń. Albert Einstein powiedział, że wyobraźnia jest ważniejsza od wiedzy, ponieważ wiedza jest ograniczona. Stąd też można wyciągnąć wniosek, że przyszłość należy do wyobraźni (zob. Mayor, 2001, s. 25).

Friedrich Hölderlin (2003), filozof i poeta niemiecki okresu romantyzmu, swój hymn Patmos rozpoczął następująco:

Bliski jest

I do ujęcia trudny jest Bóg.

Lecz gdzie jest niebezpieczeństwo, wzrasta

Także to, co ocala ${ }^{3}$.

\footnotetext{
${ }^{3}$ Tłumaczenie oryginału niemieckiego Hymnu Patmos: Stefan Napieralski (1932). Poeta i świat. Warszawa, F. Hoesick.
} 
Okazuje się, że fragment tego poematu znalazł oddźwięk zarówno w naukach o zarządzaniu, jak i w naukach o bezpieczeństwie, w tym także nauce o bezpieczeństwie ruchu drogowego. Jednym z jej zastosowań jest m.in. metoda HAZOP (Hazard and Operability Study), która jest analizą zagrożeń i zdolności operacyjnych wykorzystywanych do oceny ryzyka procesowego. Celem tej analizy jest zidentyfikowanie wszystkich potencjalnych zagrożeń i strat, jakie mogą wystąpić w przedsięwzięciach inwestycyjnych dotyczących infrastruktury drogowej. Analiza zagrożeń i zdolności operacyjnych jest strukturalną metodą identyfikacji potencjalnych zagrożeń występujących w procesach komunikacyjnych. W praktyce oznacza to systematyczny przegląd założeń projektowych i procesu technologicznego pod kątem mogących pojawić się odchyleń parametrów. Pruszkowski (2015) określa, że cechą charakterystyczną badania HAZOP jest „sesja badawcza”, podczas której interdyscyplinarny zespół, pod przewodnictwem kierownika, dokonuje systematycznego badania wszystkich istotnych elementów systemu lub projektu. Zespół ten w toku pracy identyfikuje i ujawnia wszelkie odchylenia od założeń projektu. Wykorzystuje do tego tzw. słowa kluczowe.

Najważniejszym czynnikiem poprawy bezpieczeństwa w ruchu drogowym jest wyobraźnia, przewidywanie i zapobieganie. Należy dalekowzrocznie tworzyć dalsze i bliższe wizje systemów bezpieczeństwa w ruchu drogowym. Zbyt często jesteśmy spóźnieni w przygotowaniu się do przyszłości, do biegu wydarzeń przyszłych. Teraźniejsze problemy komunikacyjne przesłaniają nam przyszłe zagrożenia. Tymczasowość jest chorobą naszych czasów. Musimy przewidywać zmiany w komunikacji, by im towarzyszyć i przystosować do potrzeb transportu tak, aby zmniejszyć zagrożenia $\mathrm{w}$ ruchu drogowym. Instytucje edukacyjne i badawcze związane $\mathrm{z}$ transportem oraz komunikacją muszą wzmocnić swoje zdolności diagnozowania, prognozowania i antycypacji.

Dobre przewidywanie zmian pozwala rozpoznać korzystne tendencje oraz zagrożenia, stałe i zmienne parametry systemu komunikacji. Przewidywanie zmian w ruchu drogowym pozwoli na przyjęcie rozwiązań i programów działań naprawczych, projektów ułatwiających zbliżenie do „przyszłości pożądanej, a nie nieuniknionej”. Bąk (2003) wskazuje, że myślenie dalekowzroczne o zapobieganiu wypadkom drogowym polega na kształceniu młodych kierowców w zakresie przysposobienia do podejmowania bezpiecznego ryzyka potrzebnego w warunkach ruchu drogowego. Szczególne miejsce w tym kształceniu zajmują młodzi kierowcy, którzy powodują często bardzo groźne wypadki drogowe (Mnttinen i in., 2009; Wundersitz, 2012). 
W XXI wieku postęp będzie bardziej opierał się na inteligencji niż na dobrach materialnych, na edukacji i mądrości niż na wiedzy. Transport XXI wieku charakteryzuje się brakiem dalekosiężnych celów edukacyjnych, dlatego należy to zmienić.

\section{PROBLEMY BEZPIECZEŃSTWA OSÓB Z NIEPEŁNOSPRAWNOŚCIĄ W SYTUACJACH RUCHU DROGOWEGO}

Odrębny problem stanowi bezpieczeństwo osób z niepełnosprawnością w sytuacjach ruchu drogowego. Składają się na to zarówno problemy kierowców z niepełnosprawnością, którzy mają prawo jazdy uprawniające ich do prowadzenia pojazdu na drogach publicznych, jak również problemy bezpieczeństwa osób z niepełnosprawnością, które korzystają z usług transportowych jako pasażerowie pojazdów przewozowych. $\mathrm{Z}$ danych przedstawionych przez Uścińską i Stasiak (2015) wynika, że w Polsce na drogach publicznych funkcjonuje ponad 200 tysięcy kierowców z niepełnosprawnością, posiadających stosowne prawo jazdy, których społeczne problemy zapewniające im bezpieczeństwo muszą zostać dostrzeżone. Przydatne dla celów psychoprofilaktyki tych problemów może być odpowiedni system szkolenia osób z niepełnosprawnością, które są kandydatami na kierowców kat. B. Podstawą dla podjęcia takich działań mogą być rezultaty analizy systemu w świetle uwarunkowań prawnych oraz doświadczeń ośrodków szkolenia kierowców w Polsce (Uścińska i Zysińska, 2015). Przewłócka, Sitek, Tarnowski i Sławek (2015) z kolei wskazali, że diagnoza zdolności do prowadzenia pojazdów w chorobach neurozwyrodnieniowych winna bardzo precyzyjnie zwracać uwagę na stopień otępienia i jego rozwój u chorego.

Autorzy zajmujący się zarówno bezpieczeństwem w przewozie osób z niepełnosprawnością (Wysocka i Kłos, 2016; Guzik-Makaruk i Jurgielewicz-Delegacz, 2016), jak i bezpieczeństwem kierowców z niepełnosprawnością w ruchu drogowym zwracają uwagę na kompleksowe wspieranie mobilości (universal design) jako na racjonalne poszerzanie zakresu samodzielności tych osób w środowisku komunikacji drogowej. 


\section{EDUKACJA KOMUNIKACYJNA}

Edukacja komunikacyjna to ogół procesów wychowawczych i kształcących, których celem są zmiany psychiczne ludzi, odpowiednie do ideałów społecznych w dziedzinie komunikacji i transportu. Edukacja jest szansą, którą należy wykorzystać w tworzeniu bezpieczeństwa w ruchu drogowym. Pierwszymi czynnikami $\mathrm{w}$ procesie edukacji są istotne zhierarchizowane i skonkretyzowane cele edukacyjne.

Cele edukacyjne to wizja skutków procesu wychowania i kształcenia. To drogowskazy pomagające orientować się, jakie kierunki i działania są istotne dla poprawy bezpieczeństwa w ruch drogowym (Grzesiuk, 2007, 2020).

Seneka o celowości działalności ludzkiej pisał: „nie ma sprzyjającego wiatru dla tych, co nie wiedzą dokąd płyną" (Myśli, s. 23). Trzeba więc na nowo przemyśleć, zhierarchizować i powiązać cele edukacji komunikacyjnej. Potrzebni są do tego ludzie, których wyobraźnia wyprzedza rozwój transportu. Niezbędne jest też przewidywanie rozwoju transportu oraz przewidywanie zagrożeń w ruchu drogowym. Należy więc tworzyć edukację transformatywną, gotową do przekształceń strukturalnych i organizacyjnych, wykraczającą poza konwencjonalne sztywne ramy kształcenia kierowców, instruktorów i wykładowców.

$\mathrm{Na}$ edukację komunikacyjną najbliższych 20 lat będą miały wpływ następujące czynniki:

- hierarchizacja i strukturalne uporządkowanie celów edukacyjnych, ze szczególnym uwzględnieniem istotnych celów wychowawczych,

- dobór oraz strukturyzacja treści edukacyjnych, dostosowanych do psychicznych procesów poznawczych i kształcących, pozwalających budować strukturę wiedzy i umiejętności,

- tworzenie multimedialnej bazy środków dydaktycznych, jako instrumentów psychicznych procesów poznawczych, interaktywnych, działaniowych,

- obserwacja, interpretacja i antycypacja zmian zachodzących w komunikacji, transporcie i ruchu drogowym, ze szczególnym uwzględnieniem wiedzy operatywnej.

Bardzo ważne będą też:

- tworzenie kontekstów edukacyjnych, uwzględniających nowe elementy wiedzy oraz

- nowych ścieżek edukacyjnych dla młodzieży, kierujących, kierowców oraz kadry szkoleniowej na różnych etapach kształcenia, 
- ewaluacja placówek oraz instytucji oświatowych i badawczych gotowych do podjęcia poważnych projektów, przedsięwzięć edukacyjnych,

- interwencja władzy publicznej, rządowej i samorządowej zdolnej do wypracowania strategii i systemów edukacji komunikacyjnej,

- ustawiczne podnoszenie kompetencji wykładowców, instruktorów i egzaminatorów, ciągłe kształcenie kierowców i kandydatów na kierowców, młodzieży oraz całego społeczeństwa z wykorzystaniem różnych form szkoleniowych.

Powyżej omawiane wyzwania edukacji komunikacyjnej nie są wystarczająco uwzględniane w praktyce, a niedostatki w zakresie kształcenia i wychowania kierowców są rażące. Bardzo istotnym elementem edukacji komunikacyjnej jest kształcenie młodych kierowców, ustawiczne dokształcanie kierowców, wychowanie komunikacyjne, motoryzacyjne oraz popularyzacja sportów motorowych (Bąk, 2003).

Jednym z ważnych obszarów edukacji komunikacyjnej jest kształcenie aktualnych i przyszłych uczestników ruchu drogowego na poziomie nauki szkolnej w zakresie szkoły podstawowej. Edukację bezpiecznego zachowania się już dzieci szkolnych, zarówno jako pieszych, jak i rowerzystów, należy rozpocząć faktycznie „od zaraz”. Do takich wniosków doszli nauczyciele oraz psychologowie w wielu krajach europejskich, USA oraz Australii (Roberts \& Kwan, 2008; Raftery \& Wundersitz, 2011; Bonham \& Johnson, 2015; Grzesiuk, 2020). Powstały szkolne programy edukacji bezpieczeństwa dzieci szkolnych w zakresie ruchu drogowego. Jednym z nich jest program ze szkół w USA: Bicycle Safer Journey, mający na celu zapewnienie dzieciom umiejętności w zakresie bezpieczeństwa jazdy rowerowej. Wykorzystuje on interaktywne lekcje wideo, aby nauczyć dzieci bezpiecznych umiejętności jazdy na rowerze, oraz zapewnia zasoby wiedzy edukacyjnej w tym zakresie dla rodziców i nauczycieli ${ }^{4}$.

Ze względu na duży obszar treściowy edukacji komunikacyjnej, w tym opracowaniu skoncentrowano się na szkoleniu i egzaminowaniu kierujących pojazdami. Na wstępie należy przypomnieć, że szkolenie i egzaminowanie stanowią integralną całość procesu edukacyjnego. Jest to stwierdzenie znane, lecz nie do końca uświadamiane przez władze rządowe, samorządowe oraz kadrę ośrodków szkolenia i egzaminowania kierowców. Egzaminowanie jest elementem procesu dydaktycznego, występującym w sprzężeniu zwrotnym ze szkoleniem. Od wielu lat nasila się, szkodliwe dla skuteczności kształcenia,

\footnotetext{
${ }^{4}$ Programy edukacyjne polskie i zagraniczne dostępne są w Internecie, zob. Netografia tego artykułu.
} 
zjawisko separacji szkolenia i egzaminowania. Egzaminowanie jest ostatnim ogniwem procesu dydaktycznego, na podstawie którego należy stwierdzić, czy cele dydaktyczne i wychowawcze zostały osiągnięte.

$\mathrm{W}$ procesie szkolenia kierowców (z gruntu rzeczy w procesie dydaktycznym) cele stanowią pierwszy i najważniejszy jego element. Cele dydaktyczne, jako świadomie założone skutki kształcenia kierowców, muszą być istotne, skonkretyzowane. Cele dydaktyczne szkolenia kierowców są projekcją wizji tworzonej przez oczekiwania społeczne w zakresie komunikacji, transportu i bezpieczeństwa ruchu drogowego.

\section{CELE POZNAWCZE W KSZTAŁCENIU KIEROWCÓW}

Cele poznawcze w kształceniu kierowców dotyczą wiedzy i jej rozumienia, a więc dotyczą podstawowych pojęć, znaków drogowych oraz znajomości zasad w ruchu drogowym (Grzesiuk, 2020).

W treściach kształcących brakuje takich tematów, jak:

- bezpieczne zachowanie w ruchu drogowym,

- rozwój wyobraźni i przewidywanie niebezpieczeństw,

- świadomość ryzyka i odpowiedzialność,

- panowanie nad emocjami i agresją w ruchu drogowym.

Jeszcze gorsza od niedostatków treściowych jest realizacja celów poznawczych przez jednostki szkolące. W wielu jednostkach kształcących, również w województwie lubelskim, szkolenie teoretyczne ogranicza się do pamięciowego ćwiczenia rozwiązywania testów. Starostwa nie prowadzą nadzoru nad bieżącą realizacją celów poznawczych, ograniczając się do wydawania zezwoleń na prowadzenie szkolenia na podstawie warunków formalnych, lokalowych i technodydaktycznych.

Nie istnieje też nadzór nad bieżącym przebiegiem szkolenia. Na podstawie wieloletnich obserwacji można stwierdzić, że kandydaci na kierowców słabo rozumieją zasady w ruchu drogowym, niedostatecznie rozumieją prawo o ruchu drogowym i nie są świadomi celów tego prawa. Testy stosowane na egzaminach teoretycznych nie stanowią narzędzia pomiaru wiedzy, są jedynie narzędziami pomiaru sprawności rozwiązywania powszechnie znanych zadań testowych.

W zastosowanych narzędziach testowych słabo znana jest charakterystyka psychometryczna, ze względu na brak ich standaryzacji i nieznajomość takich cech testu, jak (Christie, 2001; Biela i in., 2017): 
- trudność zadań,

- rzetelność,

- trafność.

Należy standaryzować narzędzia formalnego pomiaru wiedzy stosowane na egzaminach teoretycznych, gdyż opinia ekspertów, dotycząca pytań testowych, jest potrzebna, lecz niewystarczająca. Nasuwa się więc pytanie: Dlaczego nie stać nas na wysiłek intelektualny i stworzenie banku pytań, składającego się z kilku tysięcy zadań obejmujących wszystkie cele operacyjne, które zmuszałyby kandydatów na kierowców do poznania prawa o ruchu drogowym oraz poznania innych czynników, mających wpływ na bezpieczeństwo w ruchu drogowym. Kandydaci na kierowców powinni zacząć czytać ze zrozumieniem prawo o ruchu drogowym, a ośrodki szkoleniowe pomagać kursantom zrozumieć zasady bezpieczeństwa. Dotychczas realizuje się to $\mathrm{w}$ znikomym zakresie. Niski poziom wiadomości z zakresu prawa o ruchu drogowym, brak wiedzy operatywnej i proceduralnej wpływają istotnie na transformacje myślowe i stosowanie wiadomości w praktyce $\mathrm{w}$ ruchu drogowym.

\section{CELE KSZTAŁCĄCE W SZKOLENIU KIEROWCÓW}

Drugim, bardzo ważnym elementem edukacji kierowców jest realizacja celów kształcących (Grzesiuk, 2020). Dotyczą one intelektualnych i manualnych umiejętności. Jakość kształcenia umiejętności powinna być wysoka, gdyż czynności intelektualne i manualne kierowca musi wykonywać precyzyjnie w tempie narzuconym przez ruch drogowy, którego cechą jest zmienność przestrzenno-czasowa.

Kandydat na kierowcę w ramach zajęć teoretycznych i praktycznych powinien ćwiczyć następujące umiejętności intelektualne:

- analizowania sytuacji w ruchu drogowym,

- antycypacji i oceny zagrożeń występujących na drodze,

- doboru zasad prawa o ruchu drogowym do sytuacji na drodze,

- łączenia czynników mających wpływ na podjęcie decyzji o wykonywaniu określonych manewrów i podejmowania decyzji o zachowaniu na drodze.

Jest to złożony proces psychiczny, składający się z analizy, syntezy, oceny czynników oraz wyboru zachowań spośród wielu możliwych. W ramach szkolenia należy również doskonalić u kierujących: 
- koncentrację i podzielność uwagi,

- spostrzegawczość i wyobrażenia,

- transformacje myślowe i antycypacyjne myślenie.

Kształcenie takich umiejętności wymaga wysokich kwalifikacji wykładowców i instruktorów. Instruktor, podejmując się kształtować psychikę kursanta, musi zdawać sobie sprawę ze złożoności i delikatności tej struktury, że umiejętności praktyczne w dużej mierze zależą od umiejętności intelektualnych.

Kandydat na kierowcę, nabywający umiejętności motoryczne, powinien wykonywać następujące czynności poznawcze i kształcące:

- uczyć się programu wykonawczego zadania z uwzględnieniem procedur i umiejętności składowych,

- tworzyć schematy wyobrażeniowe manewrów złożonych i prostych czynności elementarnych,

- ćwiczyć proste i złożone umiejętności motoryczne,

- wzmacniać zachowania poprawne i działać awersyjnie na błędy i nieprawidłowości.

A także:

- integrować wcześniej opanowane umiejętności składowe w umiejętności złożone $\mathrm{z}$ wykorzystaniem umiejętności intelektualnych, wynikających z myślenia, a w szczególności analizy, syntezy i oceniania,

- kontrolować i oceniać wykonywane czynności,

- dokonywać korekt, przesterowań na podstawie wielkości popełnianych błędów w prowadzeniu pojazdu.

W miarę ćwiczenia umiejętności praktycznych związanych z prowadzeniem pojazdu w umyśle kursanta powstaje centralnie zorganizowany program działania motorycznego, który kontroluje ruchy. W rezultacie długotrwałego ćwiczenia poprawia się płynność i koordynacja czynności motorycznych, dzięki sprzężeniu zwrotnemu wewnętrznemu i zewnętrznemu.

Sprzężenie zwrotne wewnętrzne powstaje dzięki wymianie informacji między stawami, mięśniami i mózgiem. Bodźce pochodzące od stawów i mięśni układają się w tzw. ślad percepcyjny. Jest to rodzaj wyobrażenia ruchowego służącego jako schemat, wzorzec umysłowy zakodowany w pamięci. Sprzężenie zwrotne zewnętrzne wynika zaś z wymiany informacji spoza organizmu kierującego, to jest z przestrzeni, w której realizują się czynności prowadzenia pojazdu, w postaci skutku działania. Sprzężenie zwrotne zewnętrzne powstaje na podstawie wielkości błędu popełnionego przez kierującego w porównaniu z zapamiętanym w pamięci wzorcem (Gagne et al., 
1992; patrz także R.M.Gagne, L.J.Briggs, W.W Wager, 1992). Walton \& McKeaown (2001) z kolei zwracają uwagę na zniekształcenia u kierowców procesów percepcji prędkości pojazdów w sytuacjach ruchu drogowego.

Tymczasem w praktyce w ośrodkach szkolenia kierowców treści kształcenia $\mathrm{w}$ postaci ćwiczeń są uproszczone, realizowane mechanicznie, bez uwzględnienia procedur, psychologii i technologii kształcenia. Bardzo często w szkoleniu zadań na placu manewrowym stosuje się absurdalne ćwiczenia, polegające na mechanicznym wykonywaniu obrotu kołem kierowniczym, aż słupek karoserii samochodu pokryje się ze słupkiem na wyznaczonym torze jazdy. Nie ma w tych ćwiczeniach miejsca na kontrolę, ocenę i korektę toru jazdy samochodu. Przykładów takiego mechanicznego kształcenia jest bardzo wiele i wszystkie zasługują na krytykę. Należy jednak postawić pytania: Czy przyczynami mechanicznego uczenia się są tylko poziom i kompetencje kadry instruktorskiej? Dlaczego od Bałtyku po Tatry mechaniczne nauczanie i uczenie się znajduje szerokie zastosowanie? Należy zastanowić się, na ile system egzaminowania zezwala na takie mechaniczne podejście do szkolenia, a na ile jest jego przyczyną.

\section{CELE WYCHOWAWCZE W KSZTAŁCENIU KIEROWCÓW}

Jednym z najważniejszych zagadnień edukacji komunikacyjnej, istotnym dla bezpieczeństwa ruchu drogowego jest kształcenie systemu wartości, postaw i zachowań, a więc realizacja celów wychowawczych.

Cele wychowawcze w kształceniu kierowców są głównym czynnikiem wpływającym na bezpieczeństwo ruchu drogowego (Bąk, 2003; Grzesiuk, 2007). W edukacji komunikacyjnej są one wizją bezpieczeństwa w ruchu drogowym. W programie szkolenia kandydatów na kierowców w charakterystyce absolwenta kursu nie uwzględnia się szczegółowych celów wychowawczych. Zapis w programie szkolenia kandydatów na kierowców dotyczący celów wychowawczych ogranicza się do ogólnego sformułowania: „kursant powinien dawać dowód znajomości zachowania ostrożności i właściwej postawy w stosunku do innych uczestników ruchu", a w celach kształcących do sformułowania: „kursant powinien posiadać umiejętności bezpiecznego wykonywania wszystkich manewrów występujących w różnych sytuacjach drogowych" (Rozporządzenie Ministra Infrastruktury w sprawie szkolenia egzaminowania i uzyskiwania uprawnień przez kierujących pojazdami, instruktorów i egzaminatorów z 27 października 2005 r. Dz.U. Nr. 217 poz 
1834 ze zmianami, Dz.U. Nr. 78 poz 653 z 9 czerwca 2009 r., dalej: Rozporządzenie 2009).

Tak sformułowane cele wychowawcze są niewystarczająco skonkretyzowane. W programie szkolenia kandydatów na kierowców brakuje operacyjnych celów wychowawczych. Jest to więc sytuacja, w której kształtowanie wartości, postaw i zachowań opiera się na sformułowaniach bardzo ogólnych.

W programie szkolenia kandydatów na kierowców brakuje kształtowania następujących postaw, mających wpływ na bezpieczeństwo ruchu drogowego (Grzesiuk, 2020):

- poszanowania życia i zdrowia,

- poszanowania prawa ruchu drogowego,

- tolerancji, życzliwości i szacunku dla uczestników ruchu drogowego, krytycyzmu i skromności w stosunku do własnych umiejętności,

- asertywności i stanowczości w ograniczeniu wpływów negatywnych (alkohol i narkotyki).

A także:

- odpowiedzialności i odwagi przyznania się do błędów,

- kultury, panowania nad emocjami i agresją w ruchu drogowym,

- bezpiecznego zachowania w sytuacjach niebezpiecznych,

- ograniczonego zaufania i przewidywania zachowań innych uczestników ruchu.

W programach nauczania kandydatów na kierowców nie uwzględnia się istotnych skonkretyzowanych celów wychowawczych (Delors, 1998). Nie ma też skrystalizowanych koncepcji, kto i w jakich warunkach miałby je realizować. Praktyczna realizacja celów wychowawczych w ośrodkach szkolenia kierowców jest więc niewystarczająca.

Aby poprawić skuteczność działań wychowawczych i budowania bezpieczeństwa w ruchu drogowym, należy zaangażować administrację rządową i samorządową, szkoły, ośrodki szkolenia kierowców, ośrodki egzaminowania kierowców, telewizję, radio, internet, Safety Net i inne publikatory. Są to poważne zadania dla Krajowej i Wojewódzkiej Rady Bezpieczeństwa Ruchu Drogowego. System egzaminowania kandydatów na kierowców nie sprzyja realizacji celów wychowawczych, nie mierzy także w żadnym stopniu poziomu realizacji celów wychowawczych.

Budowa narzędzia pomiarowego sprawdzającego realizację celów wychowawczych nie jest łatwa i wymaga dużego nakładu pracy psychologów i pedagogów. Takie narzędzia pomiarowe mogą budować pracownie testów psy- 
chologicznych i pedagogicznych ${ }^{5}$. Nie ma jednak w chwili obecnej czego mierzyć, gdyż w pierwszej kolejności należy cele wychowawcze wytyczyć, sprecyzować i skonkretyzować.

\section{SYSTEM EGZAMINOWANIA KANDYDATÓW NA KIEROWCÓW A BEZPIECZEŃSTWO RUCHU DROGOWEGO}

Czy obecnie obowiązujący system egzaminowania kandydatów na kierowców przyczynia się istotnie do budowania bezpieczeństwa w ruchu drogowym? Aby odpowiedzieć na to pytanie, należy ocenić, w jakim stopniu system egzaminowania wpływa na (Grzesiuk, 2020):

- tworzenie wiedzy proceduralnej, operatywnej, gotowej do zastosowania w ruchu drogowym,

- kształcenie umiejętności intelektualnych,

- kształcenie umiejętności motorycznych w ruchu drogowym (z gruntu rzeczy umiejętności intelektualno-motorycznych),

- kształtowanie właściwych postaw i zachowań tworzących bezpieczeństwo w ruchu drogowym.

W systemie egzaminowania kandydatów na kierowców narzędziem sprawdzającym wiedzę i jej rozumienie jest test wielokrotnego wyboru. Bank pytań testowych na kat. B prawa jazdy zawiera limit powszechnie znanych i pamięciowo sprawdzanych zadań. Uczestnicy szkolenia kierowców ćwiczą rozwiązywanie testów, zapamiętując mechanicznie pytania i odpowiedzi. Test można opanować bez znajomości i rozumienia zasad obowiązujących w ruchu drogowym.

W edukacji testy kompetencyjne już na poziomie prawa jazdy kat. B są chronione, a ich publikowanie jest czynem karalnym. W testach sprawdzających wiedzę kandydatów na kierowców powszechne publikowanie zadań testowych jest normą.

Inne wady testu sprawdzającego wiedzę kandydatów na kierowców to:

- duży stopień trudności zadań testowych, wynikający z zastosowania podwójnego logicznego zaprzeczenia typu „nieprzestrzeganie nie powoduje” oraz stosowanie pytań z niejasną, niejednoznaczną intencją i domysłem „co autor miał na myśli";

\footnotetext{
${ }^{5}$ Trafność prognostyczna tych narzędzi została ustalona w 2017 r. przez zespół psychologów z KUL pod kierunkiem A. Bieli (patrz: A. Biela et al., 2017).
} 
- zadania testowe, ze względu na małą liczbę pytań i ich strukturę, nie uwzględniają sprawdzenia istotnych operacyjnych celów poznawczych i kształcących;

- mała liczba pytań w teście wzbudza wątpliwości co do rzetelności i trafności diagnostycznej stosowanego testu.

$\mathrm{Na}$ tak wątpliwym teście i tak wątpliwym pomiarze opieramy ocenę wiedzy kandydatów na kierowców. Sprzyja to powstawaniu pozorów w procesie szkolenia i egzaminowania kierowców. Kursanci udają, że uczą się zasad w ruchu drogowym, gdy w rzeczywistości ćwiczą pamięciowe rozwiązywanie testów. Egzaminatorzy udają, że pomiar wiedzy i jej rozumienia jest rzetelny, gdy tymczasem sprawdzają sprawność rozwiązywania powszechnie znanych testów.

Brak operatywnej wiedzy w postaci pojęć, znaków drogowych i zasad w ruchu drogowym przez przyszłych kierowców ogranicza stosowanie tych pojęć, zasad, a więc ogranicza możliwość kształcenia bezpiecznych zachowań. Egzamin w części teoretycznej niedostatecznie tworzy bezpieczeństwo w ruchu drogowym.

Egzamin praktyczny realizowany na placu manewrowym sprawdza umiejętności:

- przygotowania do jazdy oraz sprawdzenia stanu technicznego podstawowych elementów pojazdu, mających wpływ na bezpieczeństwo jazdy,

- ruszania z miejsca oraz jazdy pasem ruchu do przodu i tyłu, zawracania,

- parkowania skośnego, prostopadłego, równoległego,

- ruszania z miejsca do przodu na wzniesieniu,

- jazdy slalomem.

Stałe parametry toru jazdy i stanowisk do parkowania oraz kryteria oceny zadań na placu manewrowym powodują mechaniczne kształcenie umiejętności, a co za tym idzie, niską jakość tych sprawności i małą ich przydatność w ruchu drogowym.

Brakuje w tej części egzaminu sprawdzenia umiejętności: tworzenia modeli wyobrażeniowych tych zadań, kontroli i oceny pozycji pojazdu, a także umiejętności korygowania toru jazdy na podstawie wielkości błędu w sterowaniu pojazdem.

Ponadto ta część egzaminu wykazuje następujące wady:

- pamięciowe omawianie sprawdzania elementów mających wpływ na bezpieczeństwo jazdy,

- nieodpowiednie, nieadekwatne wymagania kryterialne w poszczególnych kategoriach egzaminu (np. przejechanie linii stanowiska lub potrącenie 
słupka w egzaminie kat. C, D, C+E, D+E jest zwykłym błędem i daje możliwość poprawienia zadania, natomiast w egzaminie kat. B taki sam błąd powoduje przerwanie egzaminu $\mathrm{z}$ wynikiem negatywnym).

Ponieważ przydatność praktyczna umiejętności sprawdzanych na placu manewrowym jest niewielka, to także niewielki jest wpływ tych umiejętności na bezpieczeństwo w ruchu drogowym. Zadania egzaminacyjne sprawdzane $w$ ruchu drogowym stanowią podstawę oceny umiejętności praktycznych kandydata na kierowcę (Grzesiuk, 2007; 2020).

Umiejętności sprawdzane w ruchu drogowym to:

- wjazd na drogę z obiektu przydrożnego,

- jazda drogami dwukierunkowymi i jednokierunkowymi,

- przejazd przez skrzyżowania, przejścia dla pieszych, przejazd przez torowisko oraz obok przystanków tramwajowych i autobusowych,

- parkowanie i zawracanie,

- wykonywanie manewrów: wyprzedzania, omijania, wymijania, zmiany pasa ruchu i zmiany kierunku ruchu oraz zawracania na skrzyżowaniu,

- hamowanie od prędkości $50 \mathrm{~km} / \mathrm{h}$ do zatrzymania we wskazanym miejscu, hamowanie awaryjne.

Sprawdzanie na egzaminie tych umiejętności w rzeczywistych warunkach ruchu drogowego przyczynia się w bardzo dużym stopniu do tworzenia bezpieczeństwa w ruchu drogowym.

Zmienność parametrów przestrzenno-czasowych, natężenia ruchu, warunków drogowych zmusza kursantów do: analizowania sytuacji drogowych, oceny zagrożeń, dobierania zasad z Ustawy Prawo o Ruchu Drogowym do sytuacji w ruchu drogowym oraz do podejmowania decyzji o sposobie zachowania w ruchu drogowym. Kandydat na kierowcę jest mobilizowany przez wymagania egzaminacyjne do ćwiczenia tych umiejętności. Opanowanie złożonych umiejętności intelektualnych i motorycznych przyczynia się więc do tworzenia bezpieczeństwa w ruchu drogowym.

Ta część egzaminu ma jednak również wiele wad. Niewątpliwie do nich należą następujące:

- Egzaminowanie pod kontrolą kamer czyni ten egzamin arbitralnym, skategoryzowanym, a nawet bezwzględnym.

- Wykonywanie zadań w ruchu drogowym w tempie narzuconym przez zmienność i dynamikę ruchu drogowego wywołuje u zdających wielkie zdenerwowanie, trudności $\mathrm{z}$ koncentracją oraz zakłócenia psychicznych procesów, czego nie uwzględnia się w kryterialnym systemie egzaminowania. 
- Pomiar wyników kształcenia jest „pokawałkowany”, punktatorski, strukturalnie niejednolity, co utrudnia całościową ocenę umiejętności.

- Egzamin prowadzony przy tak dużym stresie i zdenerwowaniu bardziej jest sprawdzianem panowania nad emocjami niż pomiarem wiedzy i umiejętności.

- Liczba zakładanych kamer w pojazdach i na placach manewrowych tworzy sytuacje absurdalne.

- Egzaminator nie ma odwagi podjąć decyzji na korzyść zdającego przy błędach z niewyraźnym związkiem przyczynowo-skutkowym lub w sytuacjach z pogranicza błędu.

- Egzaminator w czasie egzaminu musi zakwalifikować błąd w ciągu sekundy, a pracownicy administracyjni analizują jego decyzję przez tygodnie (ta operacja zyskała medyczne miano ,pobieranie materiału do badań”).

- Bardzo duże poczucie niesprawiedliwości i negatywne reakcje emocjonalne wywołuje rozbudowywanie przez urzędników administracji tabeli $\mathrm{nr} 12$ Rozporządzenia Ministra Infrastruktury nr 217 z dnia 27 X 2005 r. ze zmianami: w $\S 30$ ust. 4 pt 2, a konkretnie zapis „zachowanie osoby świadczące o możliwości stworzenia zagrożenia" skutkuje przerwaniem egzaminu. Pracownicy administracji samorządowej i rządowej dopisują kolejne punkty na temat, które to zachowania mogą świadczyć o możliwości tworzenia zagrożenia, wydłużając ich listę, tworzą oni w ten sposób nadinterpretację rozporządzenia.

- System egzaminowania zszyty ciasno kryteriami staje się nieludzki, wywołuje w zdających bezsilność, brak nadziei na zdanie egzaminu, a nawet agresję.

- Egzamin kandydatów na kierowców w części praktycznej konfliktuje zdających i instruktorów $\mathrm{z}$ egzaminatorami, utrudnia to tworzenie platformy działań na rzecz bezpieczeństwa ruchu drogowego.

\section{REKAPITULACJA I WNIOSKI}

Edukacja komunikacyjna w mobilnym świecie jest prawem i obowiązkiem człowieka (Delors, 1998). Edukacja komunikacyjna powinna przynosić ludziom pożytek w postaci:

- wiedzy z zakresu prawa ruchu drogowego,

- umiejętności intelektualnych i praktycznych w zakresie bezpiecznego uczestnictwa w ruchu drogowym, 
- kształtowania wartości, postaw i zachowań w ruchu drogowym,

- budowania mądrości przy tworzeniu projektów komunikacyjnych, poprawiających bezpieczeństwo w ruchu drogowym.

Polityka edukacji komunikacyjnej powinna kierować sie troską o postęp, racjonalność, ewaluację w komunikacji i transporcie. Należy podjąć pracę nad odnową i ewaluacją edukacji komunikacyjnej w celu podniesienia jej poziomu oraz skuteczności teoretycznej i praktycznej. Tworząc edukację komunikacyjną, należy uwzględnić tak fundamentalne wartości, jak: życie i zdrowie, tolerancja, zrozumienie prawa oraz odpowiedzialność, mądrość i bezpieczeństwo. Odpowiedzialność za edukację komunikacyjną ponosi całe społeczeństwo, lecz największa spoczywa na administracji rządowej i samorządowej (Grzesiuk, 2020).

- Aby poprawić bezpieczeństwo w ruchu drogowym, administracja rządowa powinna:

- Diagnozować stan bezpieczeństwa ruchu drogowego przy współudziale wyższych uczelni oraz instytutów transportu.

- Tworzyć wartościowe, profesjonalne źródła informacji dotyczące bezpieczeństwa w ruchu drogowym.

- Krytycznie ocenić dotychczasowe systemy edukacyjne z uwzględnieniem ich wad, skostniałości proceduralnych, nadinterpretacji urzędniczej, deformacji, udawania i złudzeń edukacyjnych.

- Przemyśleć i powiązać na nowo długotrwałe, dalekosiężne cele edukacyjne ze szczególnym uwzględnieniem istotnych dla bezpieczeństwa ruchu drogowego celów wychowawczych.

- Tworzyć programy szkoleniowe, uwzględniające istotne strukturalne treści dostosowane do celów edukacyjnych.

- Przemyśleć, powiązać na nowo różne cykle i formy kształcenia młodzieży szkolnej, dorosłych kierujących, instruktorów, egzaminatorów i edukatorów bezpieczeństwa ruchu drogowego.

- Podnosić na wyższy poziom kształcenie wykładowców, instruktorów, edukatorów, egzaminatorów przez kształcenie kwalifikacji pedagogicznych, psychologicznych.

- Tworzyć projekty edukacyjne i scenariusze przyszłości poprawiające bezpieczeństwo w ruchu drogowym.

- Integrować wyższe uczelnie, instytuty transportu, szkoły, organizacje i związki, ośrodki ruchu drogowego do realizacji projektów edukacyjnych.

- Tworzyć warunki nauczania w zakresie wiedzy i rozumienia prawa o ruchu drogowym, a nie sprawności rozwiązywania znanych testów. 
- Tworzyć warunki do kształcenia umiejętności intelektualnych i motorycznych, umożliwiających bezpieczne uczestnictwo w ruchu drogowym.

- Tworzyć warunki zgodnego i wspólnego budowania bezpieczeństwa w ruchu.

- Tworzyć warunki mądrego, odpowiedzialnego, samodzielnego działania w ruchu drogowym.

- Wypracowywać umiar kryterialny w systemie egzaminowania kandydatów na kierowców.

- Stwarzać profesjonalne rzetelne i trafne narzędzia pomiaru dydaktycznego przy pomocy pracowni testów psychologicznych i pedagogicznych, działających przy uniwersytetach, instytutach i wyższych uczelniach.

- Podnosić świadomość pracowników administracji samorządowej, aby poprawić rozpoznawanie problemów edukacyjnych i problemów bezpieczeństwa ruchu drogowego.

- Tworzyć warunki budowania kompetencji i autorytetów wykładowców, instruktorów i egzaminatorów w edukacji komunikacyjnej.

Edukacja powinna budować zgodę, zmniejszać konflikty na rzecz podnoszenia bezpieczeństwa w ruchu drogowym, to znaczy na rzecz ochrony życia i zdrowia. Roli edukacji w tworzeniu bezpieczeństwa w ruchu drogowym nie można przecenić: ,jest w niej ukryty skarb” (Delors, 1998), który może nas wzbogacić w mądrość i wyobraźnię potrzebną do tworzenia bezpieczeństwa (zgodnie z inspiracją bajki La Fontaine'a Oracz i jego dzieci) ${ }^{6}$.

\section{LITERATURA}

Bank Światowy (2013). Report nr 78319 Banku Światowego, Raport końcowy: Przeglad potencjalu $w$ zakresie zarzadzania bezpieczeństwem drogowym $w$ Polsce (tłumaczenie z języka angielskiego), czerwiec 2013.

BĄK, J. (2003). Wypadki drogowe a kształcenie młodych kierowców. Warszawa: ITS.

Biela, A., Rożnowski, B., Gorbaniuk, O., Biela-WarenicA, M. (2017). The External Validity of Psychometric Testing Methods and Their Meaning for Safe Road Performance. Studia Psychologica, 59(4), 256-270.

Bonham, J., \& Johnson, M. (2015). Cycling Futures. Adelaide, University of Adelaida Press.

CHRISTIE, R. (2001). The effectiveness of Driver Training as a Roads Safety Measure: A Review of the Literature. Melbourne: RACV.

${ }^{6}$ Dając tytuł raportowi: Edukacja - jest w niej ukryty skarb, Komisja Delorsa miała na myśli bajkę La Fontaine'a Oracz i jego dzieci: Nie wyzbywajcie się ojcowizny (rzecze oracz), jaka pozostawili nam przodkowie, wszak jest w niej ukryty skarb. 
DELORS, J. (1998). Edukacja: jest w niej ukryty skarb: raport dla UNESCO Międzynarodowej Komisji ds. Edukacji Dwudziestego Pierwszego Wieku. Warszawa, Wydawnictwa UNESCO.

GAGNE, R., BrigGS, L., WAGER, W. (1992). Zasady projektowania dydaktycznego. Warszawa: WSiP.

GRZESIUK, A. (2007). Infrastruktura medialna szkót zawodowych a przebieg procesów poznawczych uczniów. Warszawa: IBE.

GrZesiuk, A. (2020). Psychopedagogiczne aspekty kształcenia w zakresie bezpieczeństwa ruchu drogowego. Lublin: Wydawnictwo KUL.

GuziK-Makaruk, E.M., Jurgielewicz-Delegacz, E. (2016). Badania nad bezpieczeństwem osób z niepełnosprawnościami, w tym osób niewidomych i słabowidzących, uczestniczących w ruchu drogowym. Niepetnosprawność - zagadnienia, problemy, rozwiąania, 1(18) 27-41.

Hölderlin, F. (2003). Co się ostaje, ustanawiają poeci. Wiersze wybrane. Tłum. A. Libera. Kraków: Wydawnictwo „Znak”.

MAyor, F. (2001). Przyszłość świata, thum. J. Wolf, A. Janik, W. Rabczuk. Warszawa: Fundacja Studiów i Badań Edukacyjnych.

Krystek, R. (2005). Polityka Transportowa Państwa na lata 2005-2025. Zamość-Krasnobród: Instytut Transportu Samochodowego.

Mayor, F. (2001). Przyszłość świata. Warszawa: Fundacja Studiów i Badań Edukacyjnych.

Mynttinen, S., Sundstrom, A., Koivukoski, M, Hakuli, K., Keskinen, E., Henriksson, W. (2009). Are novice drivers overconfident? A comparison of self-assessed and examiner-assessed driver competences in a Finnish and Swedish sample. Transportation Research Part F 12(2), 120-130.

PRUSZKOWSKI, L. (2015). HAZOP jako metoda wspomagająca zarządzanie bezpieczeństwem procesowym w przedsiębiorstwie. Acta Universitatis Nicolai Copernici, 153, 7-20.

PrzewŁócka, A., Sitek, E.J., TARnowski, A., SŁaweK, J. (2015). Zdolność do prowadzenia pojazdów w chorobach neurozwyrodnieniowych przebiegających z otępieniem. Polski Przegląd Neurologiczny, 11( 3), 117-127.

RAFTERY, S.J. \& WUNDERSITZ, L.N. (2011). The efficacy of road safety education in schools: a review of current approaches. Adelaide: University of Adelaida Press.

RoBERTS, I.G., KWAN, I. (2008). School-based driver education for the prevention of traffic crashes (Review). The Cochrane Collaboration, 4. Wiley.

Rozporządzenie (2009). Rozporzadzenie Ministra Infrastruktury w sprawie szkolenia egzaminowania i uzyskiwania uprawnień przez kierujacych pojazdami, instruktorów i egzaminatorów z 27 października 2005 r. Dz.U. Nr.217 poz 1834 ze zmianami, Dz.U. Nr. 78 poz 653 z 9 czerwca 2009 r.

SENEKa (2017). Myśli. Warszawa: Aletheia.

UCIŃSKA, M., STASIAK-CIEŚLAK, B. (2016). Niepełnosprawny kierowca w ruchu drogowym: kompleksowe wspieranie mobilności. Autobusy: technika, eksploatacja, systemy transportowe, 17 (12), 489-494.

UCiŃSKA, M. STASIAK, B. (2015). Wstępna analiza sytuacji kierowców z niepełnosprawnością w Polsce w kontekście bezpieczeństwa ruchu drogowego. Transport Samochodowy, 3, 5-29.

UCIŃSKA, M., ZYSIŃSKA, M. (2015). Niepełnosprawny kandydat na kierowcę kat. B - analiza systemu szkolenia w świetle uwarunkowań prawnych oraz doświadczeń ośrodków szkolenia kierowców w Polsce. Logistyka, 3, 4883-4893.

VALÉRY, P. (2001). Eupalinos; or, The Architect. Trans. W.M. Stewart. London: Hubert Damisch. 
Walton, D.R. \& McKeaown, D.C. (2001). Drivers' biased perceptions of speed and safety compaign messages. Accident Analysis \& Prevention, 33(5), 629-640.

WUNDERSITZ, L.N. (2012). An analysis of young drivers involved in crashes using in-depth crash investigation date. Report no. CASR101. Adelaide, Center for Automotive Safety Research.

Wysocka, A., KŁos-AdAmKiewicz, Z. (2013). Aspekty bezpieczeństwa, mobilności osób niepełnosprawnych oraz prawa użytkowników transportu. Zeszyty Naukowe. Problemy Transportu i Logistyki, 24, 149-161.

\section{NETOGRAFIA}

\section{USA}

https://www.youtube.com/watch?v=dkoVxBnnGko [dostęp: 14.03.2020].

https://www.youtube.com/watch?v=ebA_J0gO11w [dostęp: 14.03.2020].

https://www.youtube.com/watch?v=PT1-mDlVyaI [dostęp: 14.03.2020].

Polska

https://www.youtube.com/watch?v=P19ocvR8VNc [dostęp: 14.03.2020].

https://www.youtube.com/watch?v=AKqDTOp5En4 [dostęp: 14.03.2020].

https://www.youtube.com/watch?v=7lglhvKXA68 [dostęp: 14.03.2020].

www.niepelnosprawni.gov.pl/dane-statystyczne/dane-demograficzne.

www.policja.pl (dane Komendy Głównej Policji dotyczące wypadków drogowych).

\section{DALEKOWZROCZNE CELE EDUKACJI KOMUNIKACYJNEJ W TWORZENIU BEZPIECZEŃSTWA RUCHU DROGOWEGO A PROCES EGZAMINOWANIA KIERUJĄCYCH POJAZDEM}

\section{STRESZCZENIE}

Dalekosiężne cele komunikacji i transportu są integracją myślenia o ruchu drogowym, działania operacyjnego, sytuacyjnego i strategicznego tworzącego: percepcję, uwagę, pamięć i myślenie, pozwalające tworzyć całość, przewidywanie, ideacje i konkretyzacje powodujące zmiany znaczeniowe i proceduralne $\mathrm{w}$ torach emocjonalnych, intelektualnych i motorycznych. Nasze działanie i myślenie można przygotować przez dostosowanie do nadchodzącej przyszłości. Wolna wola i swoboda jest ograniczona rozumieniem ograniczeń materialnych, intelektualnych i duchowych: jest w naszym władaniu i może wytworzyć dobro lub zło, bezpieczeństwo lub katastrofę ludzkości, świadomość lub niewiedzę. Edukacja jest nadzieją na dalekosiężną przyszłość. Krótkowzroczność, brak wiedzy i przewidywania jest chorobą naszych czasów. Komunikacja i transport jako ruch przenosi nas z niepewności w przewidywanie oraz w celne dopasowywanie wiedzy i umiejętności do zmieniającej się realności naszego otoczenia. Skuteczne plany, kreatywność, prowadzenie nowych technologii transportowych i ruchu o różnej modalności transportu, prowadzą do przemieszczeń tworzących wspólne budowanie i powiązania społeczne. Duma z nowoczesnych technologii transportowych i opracowań tworzy nowoczesność i współpracę społeczną, tworzy też integrację budującą. Przewidywanie i prognozowanie indywidualne i społeczne są szansą na przetrwanie, pokonanie kataklizmów i błędów cywilizacji. Z kolei niedoskonałość nowych celów rozwoju i racjonalizacji gospodarowania ziemią, tworzy brak szans na przetrwanie i na kreślenie wyobrażeń strategicznych. Nieuporządkowanie myślenia i prze- 
widywania odnośnie do transportu zmniejsza szanse na rozwój i przeżycie ludzkości. Rozwój pedagogiki i psychologii transportu tworzy szanse na pomyślne życie, pozwala na tworzenia wartości nowych, umiejętności upraktycznionych, upraktycznionej wiedzy proceduralnej i strategii w realnych warunkach ekologicznych, zdrowotnych i psychospołecznych, w jakich funkcjonują ludzie.

Słowa kluczowe: transport; przyszłość; ekonomia; wyzwanie; bezpieczeństwo; edukacja; psychologia; motoryzacja; wyobrażanie; antycypacja; obserwowanie; pamięć; uwaga; edukacja w komunikacji drogowej; cele dalekosiężne edukacji w transporcie; treść egzaminu kierowców; bezpieczeństwo ruchu drogowego.

\author{
LONG-TERM GOALS OF COMMUNICATION EDUCATION \\ IN CREATING THE FOUNDATIONS OF ROAD SAFETY BEHAVIORS \\ AND THE EFFICIENCY OF EXAMINING VEHICLE DRIVERS
}

SUMMARY

The long-term goals of communication and transport are the integration of thinking about traffic, operational behavior, situational and strategic actions creating: perceptions, attention, memory and thinking, allowing to create the whole, prediction, ideation and concretization causing changes in meaning and procedures in the emotional and motor tracks of human intellectual activity. Our actions and thinking can be prepared by adapting to the future. Free will and freedom is limited by the understanding of material, intellectual and spiritual limitations: it is in our possession and can produce good or evil, security or catastrophe of humanity, consciousness or ignorance. Education is hope for a far-reaching future. Myopia, lack of knowledge and inability to predict is a disease of our time. Communication and transport, as a move, move us from uncertainty into anticipation and accurate matching of knowledge and skills to the changing reality of our environment. Effective plans, creativity, introduction of new transport technologies and traffic with different transport modalities lead to displacements creating joint building and social connections. Pride in modern transport technologies and studies, creates modernity and social cooperation, and creates fruitful integration. Individual and social prediction and forecasting are a chance to survive, overcome cataclysms and civilization errors. In turn, the imperfection of new development goals and lack of rationalization of land management, creates a lack of opportunities for survival and for drawing strategic ideas. Disorderly thinking and anticipation about transport reduces the chances of humanity's development and survival. The development of transport pedagogy and transport psychology creates opportunities for a successful life, which allows creating new values, practical skills, practical procedural knowledge and strategies in real ecological, health and psychosocial conditions in which people operate.

Key words: transport; future; economy; challenge; safety; education; psychology; motorization; concept; anticipation; observations; memory; attention; education in road communication; long-term goals of education in transport; content of drivers' exam; road safety. 